\title{
PENGARUH TINDAKAN SUPERVISI TERDAPAT KINERJA AUDITOR INTERNAL DENGAN MOTIVASI DAN KERJASAMA SEBAGAI VARIABEL INTERVENIG \\ (Studi Kasus Bank Negara Indonesia 1946 Palembang)
}

\author{
Poppy Indriani \\ Jaka Darmawan \\ (Universitas Bina Darma, Palembang) \\ Email: poppy_ucat@yahoo.com \\ Email: jakadarmawan@yahoo.co.id
}

\begin{abstract}
Research on the supervision on job satisfaction measures have been carried out by previous researchers, but studies on the effect of supervisory actions and motivations of the performance is still rare. In this study that distinguishes it from previous research is here the researcher intends to reexamine the influence of variables on the performance of the act of supervision and motivation variables plus the variable cooperation as an intervening variable. This study uses an instrument questions for each variable.

The primary data in this study was obtained from the Internal Auditor opinion on the perception of PT. BNI 46 who complete and return the questionnaire to the researcher. Data collected by the census, which is distributed to the 13 internal auditors in the Compliance Division operating in Palembang. Furthermore then analyzed statistically assisted program SPSS 17.0. The analysis technique used is the analysis of the path.

Keywords: Action Supervision, Motivation, Collaboration, Performance, Internal Auditor and Path Analysis.

\section{LATAR BELAKANG}

Sebuah Sistem Pengendalian Internal (SPI) terdiri dari kebijakan dan prosedur yang dirancang agar manajemen mendapatkan keyakinan yang memadai bahwa perusahaan mencapai tujuan dan sasarannya. Didunia perbankan Sistem Pengendalian Internal yang efektif merupakan komponen yang penting dalam manajemen bank dan menjadi dasar bagi kegiatan operasional bank yang sehat dan aman, hal ini dikarenakan Sistem Pengendalian Intern yang efektif akan dapat membantu pihak manajemen perbankan dalam hal menjaga aset bank, menjamin tersedianya pelaporan keuangan dan manajerial yang dapat dipercaya,
\end{abstract}


meningkatkan kepatuhan bank terhadap ketentuan dan peraturan perundangan-undangan yang berlaku, serta mengurangi risiko terjadinya kerugian, penyimpangan dan pelanggaran aspek kehati-hatian.

Terselenggaranya Sistem Pengendalian Intern bank yang handal dan efektif menjadi tanggung jawab dari pengurus dan para pejabat bank. Bank Indonesia sebagai lembaga otoritas moneter mewajibkan setiap bank umum untuk memiliki system pengendalian yang intern yang baik. Sejalan dengan hal itu Bank Indonesia mengeluarkan peraturan No.8/4/PBI/1999 tanggal 20 September 1999 tentang Penerapan Standar Pelaksanaan Fungsi Audit Intern Bank Umum, bahwa bank wajib menerapkan fungsi audit intern bank sebagaimana ditetapkan dalam Standar Pelaksanaan Fungsi Audit Intern Bank (SPFAIB). Bank wajib menyusun Piagam Audit Intern (Internal Audit Charter), membentuk Satuan Kerja Audit Intern (SKAI) dan menyusun panduan audit intern. Pada tahun 2006 Bank Indonesia kembali mengeluarkan peraturan No.8/4/PBI/2006 tanggal 30 September 2006 yang mewajibkan setiap bank untuk menerapkan prinsip-prinsip Good Corporate Gorvernance. Yang dimaksud dengan Good Corporate Governance adalah suatu tata kelola Bank yang menerapkan prinsip-prinsip keterbukaan (transparency), akuntabilitas (accountability), pertanggungjawaban (responsibility), independensi (independency), dan kewajaran (fairness). (Ferdinand, 17:2006)

PT. Bank BNI 46 sebagai salah satu bank pemerintah, telah memiliki SKAI yang dikenal dengan Satuan Pengawasan Intern (SPI). Ketentuan umum mengenai pelaksanaan audit internal di PT. Bank BNI 46 telah disempurnakan berdasarkan Peraturan Bank Indonesia No 8/4/PBI/2006 tentang pelaksanaan Good Coorporate Governance bagi Bank Umum dalam pasal 50 yang berisikan :

(1) Dalam rangka memastikan kepatuhan sebagaimana dimaksud dalam Pasal 49, Bank wajib menunjuk seorang Direktur Kepatuhan dengan berpedoman pada persyaratan dan tata cara sebagaimana diatur dalam ketentuan Bank Indonesia tentang Penugasan Direktur Kepatuhan (Compliance Director) dan Penerapan Standar Pelaksanaan Fungsi Audit Intern Bank Umum.

(2) Dalam rangka membantu pelaksanaan fungsi Direktur Kepatuhan secara efektif, Bank membentuk satuan kerja kepatuhan (compliance unit) yang independen terhadap satuan kerja operasional.

(3) Satuan kerja kepatuhan sebagaimana dimaksud pada ayat (2) wajib menyusun dan mengkinikan pedoman kerja, sistem dan prosedur visi, misi, motto, tujuan dan ruang lingkup kegiatan dari SPI. 
Kegiatan utama dari SPI adalah untuk memberikan rekomendasi perbaikan terhadap efekt5itas dan efisiensi kinerja, kualitas dan efektifitas pengelolaan risiko serta kecukupan dan efektifitas pengendalian intern.

Agar setiap internal auditor di PT. Bank BNI 46 dapat melaksanakan tugas utamanya dengan baik diperlukan peranan supervisi dari lini pimpinan SPI. Menurut Comstock dalam Edi (2003) yang dimaksud dengan supervisi adalah tindakan mengawasi atau mengarahkan penyelesaian pekerjaan. Seiring dengan perjalanan waktu, supervisi dikatakan sebagai proses yang dinamis. Kemampuan supervisor dalam memberikan bantuan teknis dan dukungan pada perilaku karyawan. Demikian juga dengan iklim partisipatif yang diciptakan oleh supervisor dapat memiliki pengaruh substansial dari pada melakukan partisipasi dalam suatu keputusan spesifik, karena merasa mendapat perhatian dan dukungan yang cukup dari atasannya. Salah satu bentuk dari supervisi adalah mentoring (pelatihan) yang didefinisikan sebagai proses membentuk dan mempertahankan hubungan yang berkembang, berlangsung secara intensif dari karyawan senior (pementor) dan karyawan junior.

Kram (1998) dalam Ferdinan (3:2006) mengindentifikasikan dua kategori fungsi mentoring yaitu fungsi karir dan fungsi psikososial. Fungsi karir menunjang peserta mentoring dalam mempelajari pekerjaannya dan mempersiapkan peningkatan karir dalam organisasi. Sebaliknya fungsi psikososial berguna untuk menunjang dan memastikan perkembangan keberadaan diri peserta mentoring. Pementor dapat mengambil peran sosial aktif dengan membagi pengalaman pribadinya dan mendorong peserta mentoring untuk terbuka bila menghadapi masalah pekerjaan.

Pernyataan Standar Auditing (PSA) No. 04 tahun 2001 menyebutkan bahwa dalam standar umum yang pertama bahwa audit harus dilaksanakan oleh seseorang atau lebih yang memiliki keahlian dan pelatihan tehnis. Selanjutnya dalam PSA tersebut dikatakan bahwa dalam melaksanakan audit untuk sampai pada pernyataan pendapat, auditor senantiasa bertindak sebagai seorang ahli dalam bidang akuntansi dan bidang auditing. Pencapaian keahlian tersebut dimulai dengan pendidikan formal auditor diperluas dengan pengalaman selanjutnya dalam praktek audit.

Untuk memenuhi persyaratan sebagai seorang profesional, auditor harus melalui pelatihan teknis maupun pendidikan umum yang cukup. Selanjutnya dalam PSA tersebut dikatakan bahwa yang dimaksud dengan pelatihan seorang professional mencakup pula kesadarannya yang terus menerus terhadap perkembangan yang terjadi dalam bisnis dan profesi. Karyawan harus mempelajari, memahami dan menerapkan ketentuan-ketentuan baru dalam prinsip akuntansi dan standar auditing yang ditetapkan. Pelatihan akan meningkatkan 
kemampuan seseorang menjadi lebih baik. Dengan adanya pelatihan diharapkan dapat menumbuhkan motivasi kerja bagi seorang auditor dalam melaksanakan aktivitasnya.

Hal ini sejalan dengan telaah studi yang dilakukan oleh AECC (Accounting Education Change Commission) yang merupakan badan yang menangani pendidikan akuntansi di Amerika Serikat, telah menerbitkan Issue Statement No.4. Salah satu isi dari Issue Statement No. 4 adalah AECC Recommendations Early Work Experience yang mendorong pemberdayaan akuntan melalui tindakan supervisi yang tepat akan menumbuhkan intrinsik motivasi dan kerja sama.

Motivasi dan kerja sama merupakan proses atau faktor yang mendorong orang untuk bertindak atau berperilaku dengan cara tertentu. Proses motivasi mencakup tiga hal, yaitu: pengenalan dan penilaian kebutuhan yang belum terpuaskan, penentuan tujuan yang akan menentukan kepuasan serta penentuan tindakan yang diperlukan untuk memuaskan kebutuhan (Moekijat, 1992). Motivasi penting karena dengan motivasi diharapkan setiap individu bekerja keras dan antusias untuk mencapai hasil kerja yang tinggi.

Motivasi dan kerja sama secara umum dapat diidentifikasikan sebagai serangkaian kekuatan penggerak yang muncul dari dalam dan diluar diri masing-masing individu. Kedua kekuatan itu menimbulkan minat kerja dan berhubungan dengan tingkah laku dan menentukan arah, intensitas dan durasi dari tingkah laku atau kebiasaan individual Hasibuan (2001). Adanya tindakan supervisi dan tumbuhnya motivasi dan kerja sama sangat menentukan prestasi kerja (kinerja).

Kerjasama dalam organisasi merupakan salah satu kunci keberhasilan dalam sebuah hubungan. Kerjasama juga dapat memaksimalkan kinerja antara supervisi dan auditor intern, dengan cara melakukan koordinasi yang efektif, meningkatkan pengetahuan bagi setiap anggota dan pemecahan masalah secara bersama-sama. Selain itu Heide dan Minner dalam Syamsul Bahri (2010), memberikan dimensi tingkah laku dalam kerjasama, yaitu; penyebaran informasi (information sharing), memecahkan masalah secara bersama (problem solving), kemauan untuk menyesuaikan diri dengan perubahan (adaptability) dan pengendalian atas penggunaan kekuasaan (use of power). 


\section{TELAAH LITERATUR DAN PENGEMBANGAN HIPOTESIS}

\subsection{Desain Penelitian}

Penelitian ini menggunakan populasi auditor internal pada Auditor intern pada Divisi Audit Kepatuhan di PT Bank Negara Indonesia 1946. Selain itu dalam penelitian ini akan menggunakan tindakan supervisi sebagai variabel independen. Variabel tindakan supervisi tersebut akan diuji pengaruhnya terhadap kinerja auditor internal yang dijadikan variabel dependen dalam penelitian ini.

Disamping menggunakan tindakan supervisi sebagai variabel independen, penelitian ini juga menggunakan variabel intervening yang diprediksi akan memediasi hubungan antara variabel independen dengan variabel dependen. Motivasi dan kerja sama akan digunakan sebagai variabel intervening dalam penelitian ini. Berdasarkan tujuan penelitian, yaitu ingin menguji pengaruh tindakan supervisi terhadap kinerja auditor internal dengan motivasi dan kerja sama sebagai variabel intervening. Sifat dari penelitian ini dikategorikan penelitian penjelasan atau eksplanatory, dimana menjelaskan hubungan dan pengaruh melalui pengujian hipotesis.

\subsection{Populasi Penelitian}

Populasi dalam penelitian ini adalah seluruh Auditor Internal di bagian Satuan Pengendalian Intern pada Divisi Kepatuhan. Jumlah auditor yang terdapat pada Divisi Kepatuhan adalah 13 orang. Karena sedikit jumlah populasinya,maka peneliti menggunakan metode sensus yaitu seluruh auditor dijadikan data dalam penelitian. Bila merujuk pada pendapat beberapa penulis yang diantaranya menurut Sekaran (2003) populasi merupakan keseluruhan group dari orang-orang, peristiwa-peristiwa atau benda-benda yang ingin diteliti oleh peneliti.

Populasi adalah seluruh kumpulan elemen yang dapat digunakan untuk membuat beberapa kesimpulan. Kumpulan elemen tersebut pada hakekatnya merupakan objek dimana pengamatan akan dilakukan oleh peneliti. Jika populasi sangat besar maka perlu dilakukan pengambilan sampel (sampling). Mengingat populasi yang digunakan terbatas jumlahnya, maka metode sensus digunakan dalam penelitian ini agar dapat memperoleh tingkat respon rate yang maksimal. 


\subsection{Variabel Penelitian dan Definisi Operasional Variabel}

Operasional variabel adalah suatu yang diberikan dalam suatu variable dengan cara member arti, kemudian menspesifikasikan bagaimana kegiatan variable tersebut. Agar peneltian ini memiliki arah yang jelas maka perlu ditetapkan operasional variable seperti dalam table 3.2 dibawah ini:

Tabel 2.2

Operasional Variabel Penelitian

\begin{tabular}{|c|c|c|c|}
\hline Variable & Definisi & Dimensi & $\begin{array}{l}\text { Skala } \\
\text { Ukur }\end{array}$ \\
\hline $\begin{array}{l}\text { Variable } \\
\text { independen: } \\
\text { Tindakan } \\
\text { Supervisi }\end{array}$ & $\begin{array}{l}\text { Comstock dalam Edi (2003) mengatakan } \\
\text { supervisi merupakan tindakan mengawasi } \\
\text { atau mengarahkan penyelesaian pekerjaan. }\end{array}$ & $\begin{array}{l}\text { Tindakan } \\
\text { Pengawasan } \\
\text { dan } \\
\text { Mengarahkan }\end{array}$ & $\begin{array}{l}\text { Skala } \\
\text { likert }\end{array}$ \\
\hline Motivasi & $\begin{array}{l}\text { Motivasi kerja adalah sesuatu yang } \\
\text { memulai gerakan, sesuatu yang membuat } \\
\text { orang bertindak atau berprilaku dalam cara- } \\
\text { cara tertentu. Memotivasi orang adalah } \\
\text { menunjukkan arah tertentu kepada mereka } \\
\text { dan mengambil langkah-langkah yang perlu } \\
\text { untuk memastikan bahwa mereka sampai ke } \\
\text { suatu tujuan. (Michael Armstrong:2002). }\end{array}$ & $\begin{array}{l}\text { Kebutuhan, } \\
\text { Harapan dan } \\
\text { Mengarahkan }\end{array}$ & $\begin{array}{l}\text { Skala } \\
\text { likert }\end{array}$ \\
\hline Kerja Sama & $\begin{array}{l}\text { Kerjasama sebagai proses interaksi yang } \\
\text { dilakukan oleh individu, kelompok dan } \\
\text { organisasi untuk mendapatkan manfaat } \\
\text { (Smith, et.al., } 1995 \text { dalam Budiman } 2002 \text { ). }\end{array}$ & $\begin{array}{l}\text { Interaksi, } \\
\text { Koordinasi } \\
\text { dan Manfaat }\end{array}$ & $\begin{array}{l}\text { Skala } \\
\text { likert }\end{array}$ \\
\hline $\begin{array}{l}\text { Variable } \\
\text { dependen: } \\
\text { Kinerja }\end{array}$ & $\begin{array}{l}\text { Kinerja adalah sebagai fungsi dari interaksi } \\
\text { antara kemampuan atau ability (A), } \\
\text { motivasi atau motivasi }(\mathrm{M}) \text { dan kesempatan } \\
\text { atau opportunity (O); yaitu kinerja = } \\
\text { f(AxMxO); (Robbins, } 1999 \text { dalam } \\
\text { Hendraprijatna). }\end{array}$ & $\begin{array}{l}\text { Kemampuan, } \\
\text { Motivasi dan } \\
\text { Kesempatan }\end{array}$ & $\begin{array}{l}\text { Skala } \\
\text { likert }\end{array}$ \\
\hline
\end{tabular}


Untuk lebih jelas lagi maka pada peneliti akan menguraikan lebih lanjut dari semua variabel operasional yang ada, yang akan di teliti.

\section{Tindakan Supervisi}

Pengukuran variabel tindakan supervisi sebagai variabel independen, menggunakan instrumen yang digunakan oleh Budiman (2002). Peneliti melakukan modifikasi terhadap instrument yang digunakan Budiman dengan menyesuaikan pada kondisi lingkungan kerja para auditor internal PT Bank Negara Indonesia 1946. Jumlah pertanyaan untuk mengukur variabel tindakan supervisi terdiri 22 pertanyaan. Setiap responden diminta untuk menjawab setiap pertanyaan dengan skala Likert 5 (lima) poin, yaitu: angka 1 (Sangat Tidak Setuju), angka 2 (Tidak Setuju), angka 3 (Sedang/Netral), angka 4 (Setuju) dan angka 5 (Sangat Setuju).

\section{Motivasi dan Kerja Sama.}

Pengukuran motivasi kerja sebagai variabel intervening menggunakan instrument yang dikembangkan James E Huton (1996) dan juga digunakan Sri (2001). Peneliti melakukan modifikasi terhadap instrumen yang digunakan Budiman dengan menyesuaikan pada kondisi lingkungan kerja para auditor internal PT Bank Negara Indonesia 1946. Jumlah pertanyaan untuk mengukur variabel motivasi kerja terdiri 10 pertanyaan. Setiap responden diminta untuk menjawab setiap pertanyaan dengan skala Likert 5 (lima) poin, yaitu: angka 1 (Sangat Tidak Setuju), angka 2 (Tidak Setuju), angka 3 (Sedang/Netral), angka 4 (Setuju) dan angka 5 (Sangat Setuju).

\section{Kinerja Auditor Internal}

Yang dimaksud kinerja dalam penelitian ini adalah kinerja individu anggota suatu organisasi dalam kegiatan perencanaan dan pelaksanaan audit. Untuk mengukur variabel kinerja sebagai variabel dependen digunakan instrumen yang dikembangkan oleh Kalbers dan Fogarty (1995) dan digunakan Sumardi (2001). Peneliti melakukan modifikasi terhadap instrumen yang digunakan Kalbers dan Fogarty dimana akan disesuaikan kriteria penilaian prestasi kerja tahunan auditor internal di PT. Bank BNI 46. Jumlah pertanyaan untuk mengukur variabel kinerja terdiri 7 pertanyaan. Setiap responden diminta untuk menjawab setiap pertanyaan dengan skala Likert 5 poin, yaitu: angka 1 (Sangat Tidak Setuju), angka 2 (Tidak Setuju), angka 3 (Sedang/Netral), angka 4 (Setuju) dan angka 5 (Sangat Setuju). 


\subsection{Lokasi dan Waktu Penelitian}

Lokasi dalam penelitian ini adalah Divisi Audit Intern PT. Bank BNI 46. Untuk auditor internal yang berada pada sub Divisi Audit Kepatuhan yang berada di Palembang. Waktu penelitian yang dilakukan oleh penulis selama 6 bulan pada tahun 2013 .

\subsection{Prosedur pengumpulan data}

Studi ini dirancang sebagai studi empiris dan merupakan cross sectional study, yaitu studi yang dilakukan terhadap suatu obyek tertentu pada waktu tertentu. Data yang dikumpulkan dalam penelitian ini menggunakan metode kuesioner yang disebarkan ke auditor internal pada Divisi Kepatauhan yang berada di PT. Bank BNI 46 di Palembang. Pengambilan data disebarkan melalui dengan satu cara, yaitu kuesioner diberikan secara langsung oleh peneliti kepada para responden.

\subsection{Teknik Analisis}

Untuk menganalisis masalah penelitian ini akan menggunakan metode regresi berganda dengan bantuan program software SPSS versi 17.0. Adapun teknis analisis yang digunakan sebagai berikut.

\section{Statistik Deskriptif}

Peneliti menggunakan tabel distribusi frekwensi yang menunjukkan nilai distribusi data penelitian yang memiliki kesamaan kategori dengan menggunakan tabel distribusi frekuensi absolut yang menunjukkan rata-rata, median dan deviasi standar.

\section{Uji Reliabilitas dan Validitas}

Uji reliabilitas dimaksudkan untuk mengetahui konsistensi alat ukur dalam penggunaannya, atau dengan kata lain alat ukur tersebut mempunyai hasil yang konsisten apabila digunakan berkali-kali dalam waktu yang berbeda. Untuk uji realibilitas ini akan digunakan Tehnik Alpha Cronbach, jika suatu konstruk atau variable dikatakan reliabel jika memberikan nilai Cronbach Aplha > 0,6 (Imam, 2005). Uji validitas adalah untuk mengukur sah atau valid tidak suatu kuesioner. Suatu kuesioner dikatakan valid jika pertanyaan pada kuesioner mampu untuk mengungkapkan sesuatu yang akan diukur oleh kuesioner tersebut (Imam, 2005). Mengukur tingkat validitas dilakukan dengan melakukan korelasi antara skor butir pertanyaan dengan total skor konstruk atau variabel, dengan hipotesa, HO: skor butir pertanyaan berkorelasi positif dengan total skor konstruk 
HA: skor butir pertanyaan tidak berkorelasi positif dengan total skor konstruk

Uji signifikansi dilakukan dengan membandingkan nilai $r$ hitung dengan $r$ tabel untuk degree of freedom $(\mathrm{df})=\mathrm{n}-2$. Jika $\mathrm{r}$ hitung lebih besar dari $\mathrm{r}$ tabel dan nilai $\mathrm{r}$ positif maka pertanyaan tersebut dikatakan valid.

\section{Uji Asumsi Klasik}

\section{Uji Multikolinieritas}

Uji multikolinieritas bertujuan untuk menguji apakah model regresi ditemukan adanya korelasi antar variabel bebas (independen). Model regresi yang baik seharusnya tidak terjadi korelasi diantara variabel independen. Jika variabel independen saling berkorelasi, maka variabel ini tidak ortogonal. Variabel ortogonal adalah variable independen yang nilai korelasinya antar sesama variabel independen sama dengan nol (Imam, 2005). Untuk mendeteksi ada atau tidaknya multikolinieritas didalam model regresi akan digunakan dengan menggunakan penilaian "Variance Inflation Factor" atau "Tolerance Value". Kedua ukuran ini menunjukkan setiap variabel independen manakah yang dijelaskan oleh variabel independen lainnya.

\section{Uji Autokorelasi}

Uji asumsi klasik berupa uji autokorelasi bertujuan untuk menguji apakah dalam model regresi linear terdapat korelasi antara kesalahan pengganggu pada periode $\mathrm{t}$ dengan kesalahan pengganggu pada periode t-1 (sebelumnya). Autokorelasi muncul karena observasi yang beruntun sepanjang waktu berkaitan satu sama lain, dimana residual (kesalahan pengganggu) tidak terbebas dari satu observasi ke observasi yang lain. Masalah autokorelasi muncul pada penelitian yang menggunakan data bersifat time series data. Menurut Imam (2005) pada data yang bersifat cross section (silang waktu), masalah autokorelasi relatif jarang terjadi karena "gangguan" pada observasi yang berbeda berasal dari individu/kelompok yang berbeda.

Dalam pengujian untuk memastikan ada atau tidaknya masalah autokorelasi dilakukan dengan menggunakan uji Durbin-Watson (DW test). Nilai DW yang dihasilkan kemudian dibandingkan dengan tabelnya. Menurut Gujarati (2003) jika nilai DW berada diluar dari batas atas (du) dan batas bawah (dl) berarti tidak ada masalah autokorelasi di dalam penelitian. 


\section{Uji Heteroskedastisitas}

Uji Heteroskedastisitas bertujuan menguji apakah dalam model regresi terjadi ketidaksamaan variace dari residual satu pengamatan ke pengamatan yang lain (Imam, 2005). Jika variance dari residual satu pengamatan ke pengamatan lain tetap, maka disebut Homoskedastisitas dan jika berbeda disebut Heterokesdatisitas. Dalam penelitian ini uji heteroskedastisitas dilakukan dengan menggunakan melihat Grafik Plot antara nilai prediksi variabel dependen yaitu ZPRED dengan residualnya SRESID. Adapun dasar analisis dari Grafik Plot (Imam, 2005) yaitu jika ada pola tertentu, seperti titik-titik yang ada membentuk pola teratur (bergelombang, melebar kemudian menyempit), maka mengindikasikan telah terjadi heteroskedastisitas. Jika tidak ada pola yang jelas, serta titik-titik menyebar di atas dan di bawah angka 0 pada sumbu Y maka tidak terjadi heteroskedastisitas.

\section{Uji Normalitas}

Uji normalitas bertujuan untuk menguji apakah dalam model regresi variable residual atau pengganggu memiliki distribusi normal (Imam, 2005). Pengujian normalitas dilakukan melihat grafik histogram yang membandingkan antara data observasi dengan distribusi yang mendekati distribusi normal. Selain itu juga menggunakan grafik normal plot. Pada grafik normal plot terlihat titik-titik menyebar disekitar garis diagonal, serta penyebarannya agak menjauh dari garis diagonal.

\subsection{Analisis Statistik}

Analisis statistik yang digunakan dalam penelitian ini adalah path analysis. Untuk menentukan besar pengaruh suatu variabel terhadap variabel lainnya diperlukan persyaratan sebagai berikut: pertama, hubungan antara variabel harus merupakan hubungan linear dan aditif; kedua, semua variabel residu tidak mempunyai korelasi satu sama lain; ketiga, pola hubungan antara variabel adalah rekursif, dan keempat, skala pengukuran baik pada variabel penyebab maupun variabel akibat sekurang-kurangnya adalah interval (Nirwana, 1994 dalam H. Gunawan, 2003).

Persamaan regresinya sebagai berikut :

a. $\mathrm{Xb}=\beta 1 \mathrm{Xa}+\mathrm{e} 1$

b. $\mathrm{Y}=\beta 1 \mathrm{Xa}+\beta 2 \mathrm{Xb}+\beta_{3} \mathrm{X}_{\mathrm{c}+} \mathrm{e} 2$.

\section{Keterangan :}

Xa : Variabel Tindakan supervisi

$\mathrm{Xb}$ : Variabel Motivasi kerja 
$\mathrm{X}_{\mathrm{c}}$ : Variabel Kerja sama

Y : Variabel Kinerja auditor internal

$\beta 1, \beta 2$ : Intercept

e1 : Residual atas motivasi kerja $(\mathrm{e} 1=1-\mathrm{R} 12)$

e2 : Residual atas kinerja auditor internal (e2 = 1-R22)

\section{METODOLOGI PENELITIAN}

Dalam penelitian yang menggunakan pendekatan kuantitatif, kuesioner merupakan salah satu alat yang penting untuk pengambilan data; oleh karena itu, peneliti harus dapat membuat kuesioner dengan baik. Cara membuat kuesioner dapat dibagi dua, yaitu dari sisi format pertanyaan dan model jawaban. Disamping kuesioner, alat pengambilan data juga dapat dilakukan dengan interview. Cara-cara melakukan interview diatur secara sistematis agar dapat memperoleh informasi dan/atau data yang berkualitas dan sesuai dengan yang diinginkan.

Untuk mengetahui konsistensi alat ukur dalam penggunaannya maka digunakan Uji reliabilitas, atau dengan kata lain alat ukur tersebut mempunyai hasil yang konsisten apabila digunakan berkali-kali dalam waktu yang berbeda. Untuk uji realibilitas ini akan digunakan Tehnik Alpha Cronbach, jika suatu konstruk atau variable dikatakan reliabel jika memberikan nilai Cronbach Aplha > 0,6 (Nunnaly, 1967 dalam Imam, 2005). Uji validitas adalah untuk mengukur sah atau valid tidak suatu kuesioner. Suatu kuesioner dikatakan valid jika pertanyaan pada kuesioner mampu untuk mengungkapkan sesuatu yang akan diukur oleh kuesioner tersebut (Imam, 2005). Mengukur tingkat validitas dilakukan dengan melakukan korelasi antara skor butir pertanyaan dengan total skor konstruk atau variabel, dengan hipotesa,

HO: skor butir pertanyaan berkorelasi positif dengan total skor konstruk

HA: skor butir pertanyaan tidak berkorelasi positif dengan total skor konstruk

Uji signifikansi dilakukan dengan membandingkan nilai $r$ hitung dengan $r$ tabel untuk degree of freedom $(\mathrm{df})=\mathrm{n}-2$. Jika $r$ hitung lebih besar dari $r$ tabel dan nilai $r$ positif maka pertanyaan tersebut dikatakan valid. 


\subsection{Uji Validitas}

Berdasarkan hasil penghitungan menggunakan program SPSS diperoleh hasil pengujian validitas untuk variabel Tindakan Supervisi, Motivasi, Kerjasama dan Kinerja Auditor Internal masing - masing dapat diuraikan sebagai berikut:

Tabel 3.1

Hasil Pengujian Validitas Variabel Tindakan Supervisi

\begin{tabular}{|c|c|c|c|c|}
\hline Keterangan & Pernyataan & Skor_Total & Pernyataan & Skor_Total \\
\hline $\begin{array}{l}\text { Pearson Correlation } \\
\text { Sig. (2-tailed) } \\
\text { N }\end{array}$ & TS1 & $\begin{array}{r}.671^{*} \\
.012 \\
13\end{array}$ & TS13 & $\begin{array}{r}.671^{*} \\
.012 \\
13\end{array}$ \\
\hline $\begin{array}{l}\text { Pearson Correlation } \\
\text { Sig. (2-tailed) } \\
\text { N }\end{array}$ & $\mathrm{TS} 2$ & $\begin{array}{r}.867^{* *} \\
.000 \\
13\end{array}$ & TS14 & $\begin{array}{r}.770^{* * *} \\
.002 \\
13\end{array}$ \\
\hline $\begin{array}{l}\text { Pearson Correlation } \\
\text { Sig. (2-tailed) } \\
\mathrm{N}\end{array}$ & TS3 & $\begin{array}{r}.809^{* *} \\
.001 \\
13\end{array}$ & TS15 & $\begin{array}{r}.776^{* *} \\
.002 \\
13\end{array}$ \\
\hline $\begin{array}{l}\text { Pearson Correlation } \\
\text { Sig. (2-tailed) } \\
\mathrm{N}\end{array}$ & TS4 & $\begin{array}{r}.677^{*} \\
.011 \\
13\end{array}$ & TS16 & $\begin{array}{r}.844^{* *} \\
.000 \\
13\end{array}$ \\
\hline $\begin{array}{l}\text { Pearson Correlation } \\
\text { Sig. (2-tailed) } \\
\mathrm{N}\end{array}$ & TS5 & $\begin{array}{r}.770^{* *} \\
.002 \\
13\end{array}$ & TS17 & $\begin{array}{r}.735^{* *} \\
.004 \\
13\end{array}$ \\
\hline $\begin{array}{l}\text { Pearson Correlation } \\
\text { Sig. (2-tailed) } \\
\text { N }\end{array}$ & TS6 & $\begin{array}{r}.770^{* *} \\
.002 \\
13\end{array}$ & TS18 & $\begin{array}{r}.809^{* *} \\
.001 \\
13\end{array}$ \\
\hline $\begin{array}{l}\text { Pearson Correlation } \\
\text { Sig. (2-tailed) } \\
\text { N }\end{array}$ & TS7 & $\begin{array}{r}.867^{* *} \\
.000 \\
13\end{array}$ & TS19 & $\begin{array}{r}.677^{*} \\
.011 \\
13\end{array}$ \\
\hline $\begin{array}{l}\text { Pearson Correlation } \\
\text { Sig. (2-tailed) } \\
\mathrm{N}\end{array}$ & TS8 & $\begin{array}{r}.771^{\text {** }} \\
.002 \\
13\end{array}$ & TS20 & $\begin{array}{r}.757^{* *} \\
.003 \\
13\end{array}$ \\
\hline $\begin{array}{l}\text { Pearson Correlation } \\
\text { Sig. (2-tailed) } \\
\text { N }\end{array}$ & TS9 & $\begin{array}{r}.776^{* *} \\
.002 \\
13\end{array}$ & TS21 & $\begin{array}{r}.844^{* *} \\
.000 \\
13\end{array}$ \\
\hline $\begin{array}{l}\text { Pearson Correlation } \\
\text { Sig. (2-tailed) } \\
\text { N }\end{array}$ & TS10 & $\begin{array}{r}.844^{* *} \\
.000 \\
13\end{array}$ & TS22 & $\begin{array}{r}.735^{* *} \\
.004 \\
13\end{array}$ \\
\hline $\begin{array}{l}\text { Pearson Correlation } \\
\text { Sig. (2-tailed) } \\
\text { N }\end{array}$ & TS11 & $\begin{array}{r}.757^{* *} \\
.003 \\
13\end{array}$ & Skor Total & $\begin{array}{r}1 \\
13\end{array}$ \\
\hline $\begin{array}{l}\text { Pearson Correlation } \\
\text { Sig. (2-tailed) } \\
\text { N }\end{array}$ & TS12 & $\begin{array}{r}.638^{*} \\
.019 \\
13\end{array}$ & & \\
\hline
\end{tabular}


Tabel 3.2

Hasil Pengujian Validitas Variabel Motivasi

\begin{tabular}{|l|r|r|r|r|}
\hline \multicolumn{1}{|c|}{ Keterangan } & Pernyataan & TOTM & Pernyataan & TOTM \\
\hline Pearson Correlation & & $.838^{* *}$ & & $.608^{*}$ \\
Sig. (2-tailed) & & 0 & & 0.027 \\
N & M1 & 13 & M4 & 13 \\
\hline Pearson Correlation & & $.756^{* *}$ & & $.867^{* *}$ \\
Sig. (2-tailed) & & 0.003 & & 0 \\
N & M2 & 13 & M5 & 13 \\
\hline Pearson Correlation & & $.754^{* *}$ & & 1 \\
Sig. (2-tailed) & & 0.003 & & 13 \\
N & M3 & 13 & TOTM & \\
\hline
\end{tabular}

Tabel 3.3

Hasil Pengujian Validitas Variabel Kerjasama

\begin{tabular}{|l|r|r|r|r|}
\hline \multicolumn{1}{|c|}{ Keterangan } & Pernyataan & \multicolumn{1}{c|}{ TOTKJ } & Pernyataan & TOTKJ \\
\hline Pearson Correlation & & $.911^{* *}$ & & $.911^{* *}$ \\
Sig. (2-tailed) & & 0 & & 0 \\
N & KJ1 & 13 & KJ4 & 13 \\
\hline Pearson Correlation & & $.741^{* *}$ & & $.859^{* *}$ \\
Sig. (2-tailed) & & 0.004 & & 0 \\
N & KJ2 & 13 & KJ5 & 13 \\
\hline Pearson Correlation & & $.929^{* *}$ & & 1 \\
Sig. (2-tailed) & & 0 & & 13 \\
N & & 13 & TOTKJ & \\
\hline
\end{tabular}

Tabel 3.4

Hasil Pengujian Validitas Variabel Kinerja Auditor Internal

\begin{tabular}{|l|c|r|c|r|}
\hline \multicolumn{1}{|c|}{ Keterangan } & Pernyataan & TOTKAI & Pernyataan & TOTKAI \\
\hline Pearson Correlation & & $.832^{* *}$ & & $.611^{*}$ \\
Sig. (2-tailed) & KAI1 & .000 & KAI6 & .026 \\
N & & 13 & & 13 \\
\hline Pearson Correlation & & $.874^{* *}$ & & $.738^{* * *}$ \\
Sig. (2-tailed) & KAI2 & .000 & KAI7 & .004 \\
N & & 13 & & 13 \\
\hline Pearson Correlation & & $.887^{* *}$ & & $.874^{* * *}$ \\
Sig. (2-tailed) & KAI3 & .000 & KAI8 & .000 \\
N & & 13 & & 13 \\
\hline Pearson Correlation & & $.633^{*}$ & & 1 \\
Sig. (2-tailed) & KAI4 & .020 & TOTKAI & \\
N & & 13 & & 13 \\
\hline Pearson Correlation & & $.736^{* *}$ & & \\
Sig. (2-tailed) & KAI5 & .004 & & \\
N & & 13 & & \\
\hline
\end{tabular}


Berdasarkan hasil uji validitas di atas diketahui bahwa semua hasil pengujian valid dikarenakan nilai korelasi antar skor semuanya lebih kecil dari nilai 0,05. Maka dapat diambil kesimpulan bahwa data variabel Tindakan Supervisi, Motivasi, Kerjasama dan Kinerja Auditor Internal yang diperoleh mempunyai nilai yang valid.

\subsection{Uji Reliabilitas}

Untuk mengetahui reliabilitas data yang diperoleh, dilihat dari nilai Cronbach Alpha setiap variabel yang dibandingkan dengan nilai koefisien yang telah ditetapkan. Adapun hasil pengujian reliabilitas untuk variabel Tindakan Supervisi, Motivasi, Kerjasama dan Kinerja Auditor Internal dapat dilihat pada tabel di bawah ini:

\section{Tabel 3.5}

\section{Hasil Uji Reliabilitas}

\begin{tabular}{|l|c|c|}
\hline \multicolumn{1}{|c|}{ Variabel } & Cronbach Alpha & Keterangan \\
\hline Tindakan Supervisi & 0,964 & Reliabel \\
\hline Motivasi & 0,808 & Reliabel \\
\hline Kerjasama & 0,904 & Reliabel \\
\hline Kinerja Auditor Internal & 0,899 & Reliabel \\
\hline
\end{tabular}

Berdasarkan hasil uji reliabilitas di atas menunjukkan bahwa semua varibel yaitu Tindakan Supervisi, Motivasi, Kerjasama dan Kinerja Auditor Internal memiliki nilai yang reliabel, hal ini dapat dilihat dari nilai cronbach alpha yang lebih besar dari 0,6. Kesimpulan, oleh karena kuisioner telah dinyatakan valid dan reliabel, maka kuisioner tersebut layak disebarkan kepada responden untuk mengadakan penelitian.

Untuk kedepannya diharapkan dilakukan penelitian serupa mengenai pengaruh tindakan supervisi terhadap kinerja auditor internal dengan variabel motivasi dan kerjasama sebagai variabel intervening namun populasi dan sampelnya diperluas dengan mengambil beberapa perbankan yang ada di Indonesia, sehingga hasilnya dapat diperoleh gambaran secara luas pada dunia perbankan mengenai pengaruh tindakan supervisi terhadap kinerja auditor internal dengan variabel motivasi dan kerjasama sebagai variabel intervening.

Kemudian penelitian yang akan datang juga diharapkan dapat mengembangkan model yang sudah ada dengan menambahkan variabel-variabel yang mempengaruhi kinerja kerja internal auditor, misalnya kepuasan kerja dan budaya organisasi serta loyalitas. 


\subsection{Analisis Statistik}

Salah satu ciri yang menonjol dalam penelitian yang menggunakan pendekatan kuantitatif ialah adanya analisa statistik. Analisa statistik digunakan untuk membantu peneliti mengetahui makna hubungan antar variable. Sampai saat ini, analisa statistik merupakan satu-satunya alat yang dapat dipertanggungjawabkan secara ilmiah untuk menghitung besarnya hubungan antar variabel, untuk memprediksi pengaruh variabel bebas terhadap variabel tergantung, untuk melihat besarnya pesentase atau rata-rata besarnya suatu variable yang kita ukur. Untuk menganalisis masalah penelitian ini akan menggunakan metode regresi berganda dengan bantuan program software SPSS versi 17.0.

Peneliti menggunakan tabel distribusi frekwensi yang menunjukkan nilai distribusi data penelitian yang memiliki kesamaan kategori dengan menggunakan tabel distribusi frekuensi absolut yang menunjukkan rata-rata, median dan deviasi standar.

Berdasarkan hasil perhitungan diperoleh distribusi frekuensi masing - masing variabel sebagai berikut:

Tabel 3.6

\section{Descript5e Statistics}

\begin{tabular}{|l|r|r|r|r|r|}
\hline & \multicolumn{1}{|c|}{ N } & Minimum & Maximum & \multicolumn{1}{c|}{ Mean } & \multicolumn{1}{c|}{ Std. Deviation } \\
\hline Tindakan Supervisi & 13 & 3.36 & 5.00 & 4.0946 & .49154 \\
Motivasi Kerja & 13 & 3.40 & 5.00 & 4.1385 & .53157 \\
Kerjasama & 13 & 3.00 & 5.00 & 4.1692 & .57065 \\
Kinerja Auditor Internal & 13 & 3.38 & 5.00 & 4.0015 & .49435 \\
Valid N (listwise) & 13 & & & & \\
\hline
\end{tabular}

1. Variabel Tindakan Supervisi

Data variabel Tindakan Supervisi dikumpulkan melalui penyebaran kuisioner kepada responden. Berdasarkan hasil pengolahan data, diketahui bahwa distribusi nilai jawaban responden sebagai berikut: interval nilai (range) sebesar 1,64 yang diperoleh dari selisih nilai tertinggi jawaban responden sebesar 5 dengan nilai terendah jawaban responden sebesar 3,36. Kemudian diperoleh nilai rata-rata jawaban responden sebesar 4,09 dengan simpangan baku (standar deviasi) sebesar 0,49.

2. Variabel Motivasi Kerja

Data variabel Motivasi Kerja dikumpulkan melalui penyebaran kuisioner kepada responden. Berdasarkan hasil pengolahan data, diketahui bahwa distribusi nilai jawaban responden sebagai berikut: interval nilai (range) sebesar 1,60 yang diperoleh dari selisih 
nilai tertinggi jawaban responden sebesar 5 dengan nilai terendah jawaban responden sebesar 3,40. Kemudian diperoleh nilai rata-rata jawaban responden sebesar 4,14 dengan simpangan baku (standar deviasi) sebesar 0,53.

3. Variabel Kerjasama

Data variabel Kerjasama dikumpulkan melalui penyebaran kuisioner kepada responden. Berdasarkan hasil pengolahan data, diketahui bahwa distribusi nilai jawaban responden sebagai berikut: interval nilai (range) sebesar 2 yang diperoleh dari selisih nilai tertinggi jawaban responden sebesar 5 dengan nilai terendah jawaban responden sebesar 3. Kemudian diperoleh nilai rata-rata jawaban responden sebesar 4,17 dengan simpangan baku (standar deviasi) sebesar 0,57.

4. Variabel Kinerja Audit Internal

Data variabel Tindakan Supervisi dikumpulkan melalui penyebaran kuisioner kepada responden. Berdasarkan hasil pengolahan data, diketahui bahwa distribusi nilai jawaban responden sebagai berikut: interval nilai (range) sebesar 1,62 yang diperoleh dari selisih nilai tertinggi jawaban responden sebesar 5 dengan nilai terendah jawaban responden sebesar 3,38. Kemudian diperoleh nilai rata-rata jawaban responden sebesar 4 dengan simpangan baku (standar deviasi) sebesar 0,49.

\subsection{Menggunakan Komputer Untuk Analisis Data}

Dengan berkembangnya teknologi komputer yang semakin canggih dan dituntutnya melakukan penelitian secara lebih cepat serta kemungkinan besarnya jumlah data, maka seorang peneliti memerlukan bantuan komputer untuk melakukan analisa data. Banyak perangkat lunak yang telah dikembangkan untuk membantu peneliti dalam melakukan analisa data, baik yang bersifat pengelohan data maupun analisanya. Salah satu program yang popular ialah program SPSS vers 17.0 


\section{Uji Asumsi Klasik}

\section{Uji Multikolinieritas}

Berdasarkan pengujian diperoleh hasil uji multikolinieritas sebagai berikut:

Tabel 3.7

\section{Hasil Uji Multikolinieritas}

\begin{tabular}{|l|r|r|}
\hline \multirow{2}{*}{ Model } & \multicolumn{2}{|c|}{ Collinearity Statistics } \\
\cline { 2 - 3 } & Tolerance & \multicolumn{1}{c|}{ VIF } \\
\hline $1 \quad$ (Constant) & & \\
Tindakan Supervisi & .736 & 1.359 \\
Motivasi Kerja & .264 & 3.792 \\
Kerjasama & .295 & 3.387 \\
\hline
\end{tabular}

Berdasarkan tabel di atas terlihat nilai VIF untuk masing - masing variabel yaitu Tindakan Supervisi 1,359; variabel Motivasi Kerja 3,792 dan variabel kerjasama 3,387. Oleh karena nilai VIF masing - masing variabel $<10$, maka dapat disimpulkan bahwa pada model regresi tidak ditemukan adanya masalah multikolinieritas.

\section{Uji Autokorelasi}

Berdasarkan perhitungan menggunakan program SPSS diperoleh hasil uji autokorelasi sebagai berikut:

\section{Tabel 3.8}

\section{Hasil Uji Autokorelasi}

\begin{tabular}{|l|r|r|r|r|r|}
\hline \multicolumn{7}{|c|}{ Model Summary } \\
\hline Model & \multicolumn{1}{|c|}{$\mathrm{R}$} & R Square & $\begin{array}{c}\text { Adjusted R } \\
\text { Square }\end{array}$ & $\begin{array}{c}\text { Std. Error of } \\
\text { the Estimate }\end{array}$ & $\begin{array}{c}\text { Durbin- } \\
\text { Watson }\end{array}$ \\
\hline 1 & $.967^{\mathrm{a}}$ & .936 & .914 & .14456 & 1.908 \\
\hline
\end{tabular}

a. Predictors: (Constant), Kerjasama, Tindakan Supervisi, Motivasi Kerja

b. Dependent Variable: Kinerja Auditor Internal

Berdasarkan output di atas di dapat nilai DW yang dihasilkan dari model regresi adalah 1,908 sedangkan dari tabel DW diperoleh nilai dL 0,715 dan dU 1,816. Oleh sebab itu dapat dijelaskan bahwa nilai DW terletak di antara $\mathrm{dU}<\mathrm{DW}<(4-\mathrm{dU})$ yang berarti tidak terdapat autokorelasi. 


\section{Uji Heteroskedastisitas}

Berdasarkan pengujian menggunakan program SPSS diperoleh hasil pengujian heteroskedastisitas sebagai berikut:

Scatterplot

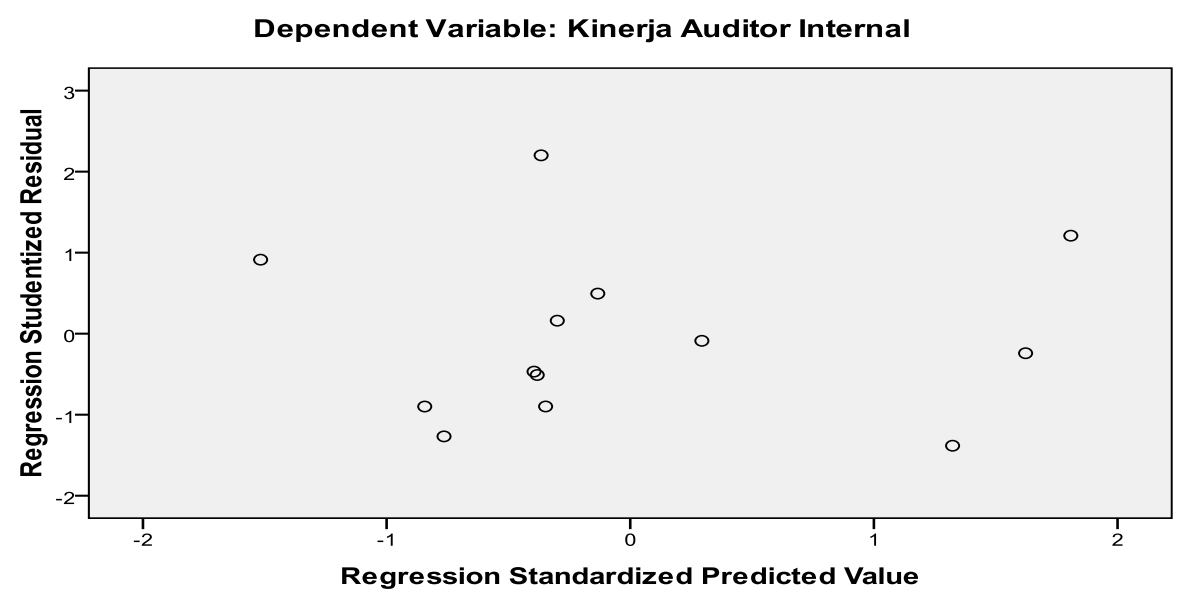

Gambar 3.1

Hasil Uji Heteroskedastisitas

Berdasarkan output di atas terlihat penyebaran titik - titik tidak membentuk pola tertentu sehingga dapat dikatakan bahwa tidak terdapat gangguan heteroskedastisitas.

\section{Uji Normalitas}

Berdasarkan hasil pengolahan data diperoleh hasil pengujian normalitas sebagai berikut:

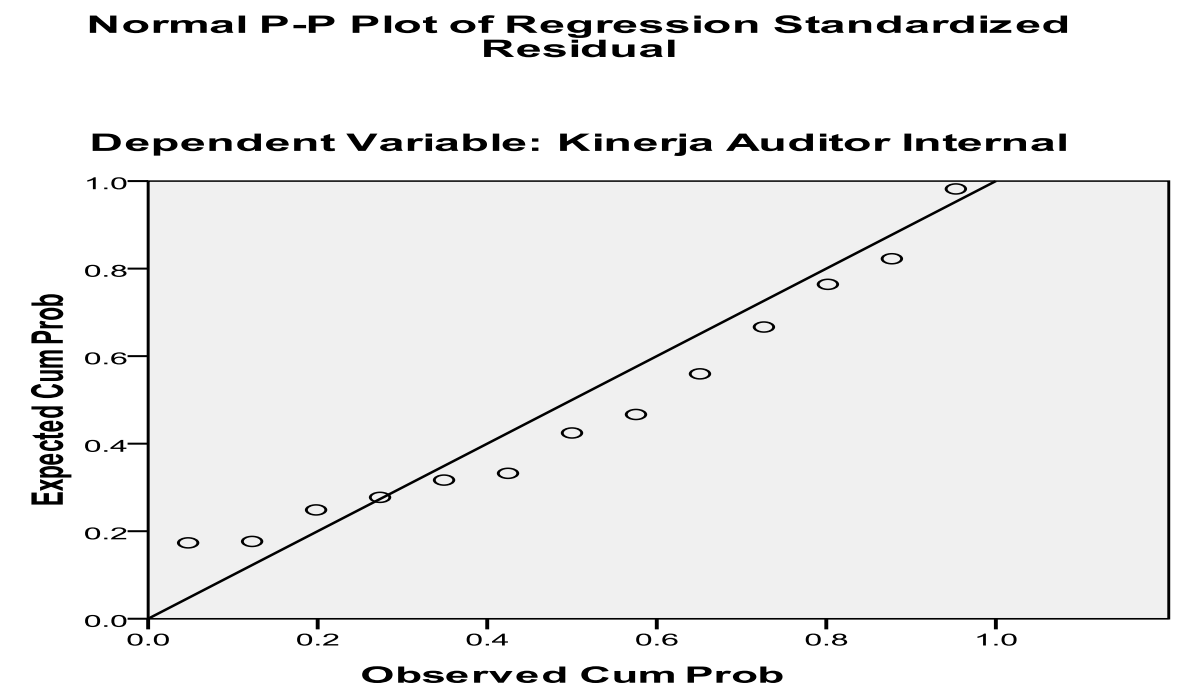

Gambar 3.2 


\section{Hasil Uji Normalitas}

Berdasarkan gambar di atas terlihat penyebaran titik - titik mendekati garis diagonal, hal ini berarti bahwa data berdistribusi normal.

\section{HASIL PENELITIAN DAN PEMBAHASAN}

\subsection{Pengaruh Tindakan Supervisi Terhadap Kinerja Auditor Internal}

\section{Secara Langsung dan Melalui Motivasi Kerja}

Terlihat pada $\rho$-value (kolom sig) $=0,000$ yang lebih kecil dari 0,05 atau pada kolom $\mathrm{t}$ $=$ 9,960 yang lebih besar dari t tabel sebesar 2,262 hal ini berarti bahwa variabel Tindakan Supervisi berpengaruh terhadap Kinerja Auditor Internal.

Untuk mengetahui besarnya pengaruh tersebut dapat diuraikan sebagai berikut:

Pengaruh Langsung

$$
\begin{aligned}
& =\rho_{\mathrm{YX} 1} \times \rho_{\mathrm{YX} 1} \\
& =0,980 \times 0,980 \\
& =0,9604
\end{aligned}
$$

Pengaruh melalui hubungan korelatif dengan Motivasi

$$
\begin{aligned}
& =\rho_{Y X 1} \times r_{X 1 X 2 a} \times \rho_{Y X 2 a} \\
& =0,980 \times 0,513 \times 0,042 \\
& =0,02111508
\end{aligned}
$$

Pengaruh Tindakan Supervisi Terhadap Kinerja Auditor Internal Secara Total melalui

Motivasi Kerja adalah 0,9604 + 0,02111508 = 0,98151508

\section{Secara Langsung dan Melalui Kerjasama}

Terlihat pada $\rho$ - value (kolom sig) $=0,000$ yang lebih kecil dari 0,05 atau pada kolom $\mathrm{t}$ = 9,960 yang lebih besar dari t tabel sebesar 2,262 hal ini berarti bahwa variabel Tindakan Supervisi berpengaruh terhadap Kinerja Auditor Internal.

Untuk mengetahui besarnya pengaruh tersebut dapat diuraikan sebagai berikut:

Pengaruh Langsung

$$
\begin{aligned}
& =\rho_{Y X 1} \times \rho_{Y X 1} \\
& =0,980 \times 0,980 \\
& =0,9604
\end{aligned}
$$


Pengaruh melalui hubungan korelatif dengan Kerjasama

$$
\begin{aligned}
& =\rho_{Y X 1} \times r_{X 1 X 2 b} \times \rho_{Y X 2 b} \\
& =0,980 \times 0,419 \times 0,085 \\
& =0,0349027
\end{aligned}
$$

Pengaruh Tindakan Supervisi Terhadap Kinerja Auditor Internal Secara Total melalui

Kerjasama adalah $0,9604+0,0349027=0,9953027$

\subsection{Pengaruh Tindakan Supervisi Terhadap Motivasi Kerja}

Berdasarkan hasil perhitungan terlihat pada $\rho$ - value (kolom sig) $=0,102$ yang lebih besar dari 0,05 atau pada kolom $\mathrm{t}=1,783$ yang lebih kecil dari $\mathrm{t}$ tabel sebesar 2,262 hal ini berarti bahwa variabel Tindakan Supervisi tidak berpengaruh terhadap Motivasi Kerja.

\subsection{Pengaruh Tindakan Supervisi Terhadap Kerjasama}

Berdasarkan hasil perhitungan terlihat pada $\rho$ - value (kolom sig) $=0,226$ yang lebih besar dari 0,05 atau pada kolom $\mathrm{t}=1,282$ yang lebih kecil dari $\mathrm{t}$ tabel sebesar 2,262 hal ini berarti bahwa variabel Tindakan Supervisi tidak berpengaruh terhadap Kerjasama.

Secara ringkas hasil penelitian tersebut dapat digambarkan pada gambar di bawah ini:

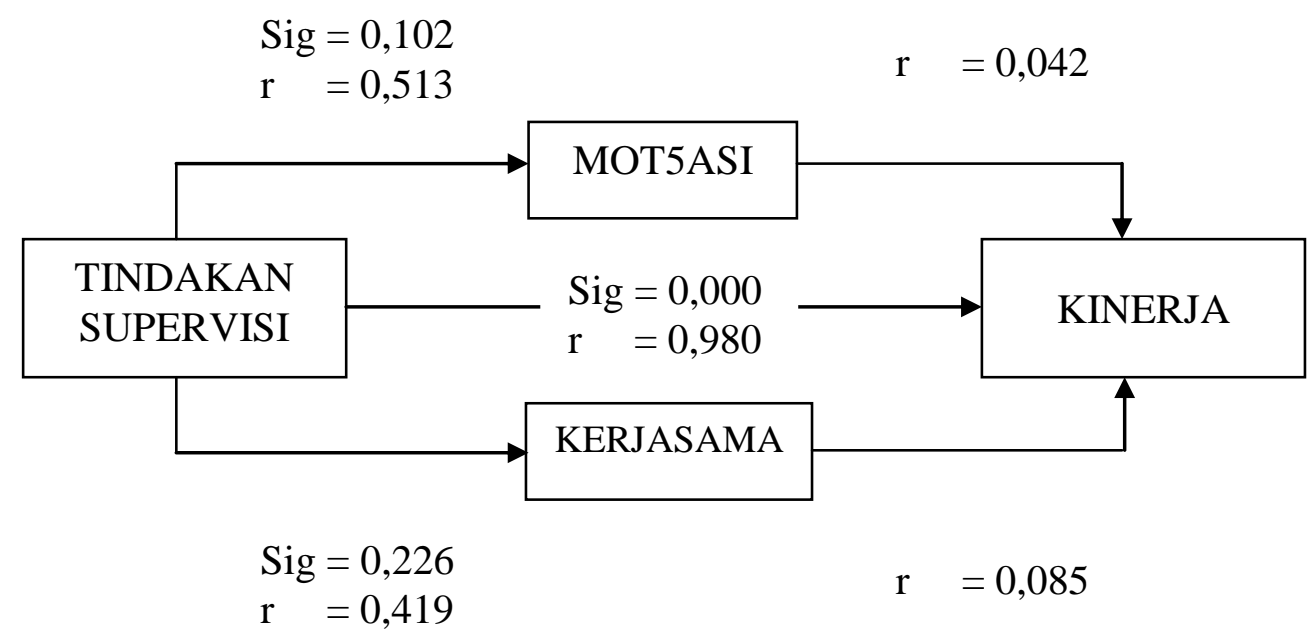




\section{KESIMPULAN DAN SARAN}

\subsection{Kesimpulan}

Berdasarkan hasil analisis penelitian ini menunjukkan bahwa tindakan supervisi secara langsung memacu kinerja auditor internal dalam melakukan tugas dan fungsinya sehari-hari. Berdasarkan hal tersebut maka dapat dijelaskan bahwa tindakan supervisi akan lebih bermanfaat guna meningkatkan kinerja auditor internal jika dilakukan dengan melakukan kerjasama yang baik. Selanjutnya variabel Tindakan Supervisi tidak berpengaruh baik kepada motivasi maupun kerjasama.

\subsection{Saran-saran}

Penelitian yang akan datang diharapkan dapat mengembangkan model yang sudah ada dengan menambahkan variabel-variabel yang mempengaruhi kinerja kerja internal auditor, misalnya kepuasan kerja dan budaya organisasi serta loyalitas. Penelitian mendatang juga diharapkan dapat mencari strategi untuk meningkatkan jumlah besaran sampel yang ada. Selain itu diharapkan dapat memperluas populasi penelitian. Populasi penelitian tidak hanya diambil dari kondisi pada bank pemerintah namun bisa dikembangkan dengan membandingkan dengan beberapa bank yang berstatus swasta nasional maupun swasta asing.

\section{DAFTAR PUSTAKA}

Amstrong, Michael, 2002, A Handbook of Human Resources Management Practice, 10th Edition, London: Kogan Page Limited Pentoville Read

Baridwan, 2004, Intermediate Accounting, Edisi kedelapan, BPFE Yogyakarta, Yogyakarta.

Budiman Slamet, 2002. "Pengaruh Tindakan Supervisi Terhadap Kinerja Auditor Yang

Melakukan Audit Khusus : Studi Empiris Pada Kantor Perwakilan BPKP”, Tesis

Program Pascasarjana Universitas Diponegoro (tidak untuk dipublikasikan),

Semarang

Edi Fitriandi Nursitti, 2003, "Pengaruh Aspek Kepemimpinan dan Mentoring dalam

Tindakan Supervisi terhadap Kepuasan Kerja Karyawan Bagian Akuntansi, Univristas Sebelas Maret, Surakarta 
H. Gunawan Aji, 2003. "Pengaruh Etika Islam Terhadap Kinerja dengan Motivasi kerja Sebagai Variabel Intervening : Studi Empiris Terhadap Internal Auditor Bank Di Jawa Tengah", Tesis Program Pascasarjana Universitas Diponegoro (tidak untuk dipublikasikan), Semarang.

Hendraprijatna68.files.wordpress.com/2012/.../25 Agustus 2013.

Hery, 2008, Pengantar Akuntansi 1, Fakultas Ekonomi Un5ersitas Indonesia, Jakarta. Imam, 2005. “Aplikasi Analisis Multivariate Dengan Program SPSS”. Badan Penerbit Universitas Diponegoro, Semarang.

Malayu Hasibuan SP, 1997. "Organisasi dan Motivasi”, Penerbit Bumi Aksara, Jakarta. Irvan Martamin, 2006, “Analisis Pengaruh Tindakan Aupervisi terhadap epuasan Kerja Auditor”, Program Magister Management Akuntansi, Universitas Diponegoro.

Manajemen Sumber Daya Manusia. Penerbit : Bumi. Aksara. Jakarta. Heidjrachman Dan Husnan,Suad. 2002.

Sawyer,Edisi 5, 2005, Audit Internal I, Salemba Empat, Jakarta

Sri Trisnaningsih, 2001. "Pengaruh Komitmen Terhadap Kepuasan Kerja Auditor Dengan Motivasi Sebagai Variabel Intervening : Studi Empiris Pada Kantor Akuntan Publik Di Jawa Timur“, Tesis Program Pascasarjana Universitas Diponegoro (tidak untuk dipublikasikan), Semarang.

Sumardi, 2001. "Analisis Pengaruh Pengalaman Terhadap Professionalisme Serta Pengaruh professionalisme Terhadap Kinerja Dan kepuasan Kerja : Studi Empiris Auditor BPKP“, Tesis Program Pascasarjana Universitas Diponegoro (tidak untuk dipublikasikan), Semarang. 